\title{
Global Business Research and Strategic Planning Tools
}

\author{
Dr. Basil J. Janavaras \\ Professor of International Business \\ Minnesota State University, Mankato, USA \\ Dr. Emanuel Gomes \\ Senior Lecturer in Corporate Strategy \\ Coventry University, UK
}

\begin{abstract}
The web-based tools discussed in this paper support students and business practitioners alike in their roles as managers and decision makers in a global setting. More specifically, the software will enable users to perform a situation analysis of a company, determine best markets for a company's products/services and develop an international business plan online. Project-Based Learning (PBL) is a teaching and learning method widely used at universities and businesses around the world. The three software - the Global Market Potential System Online (www.globalmarketpotential.com ), the Global Marketing Management System Online (GMMSO, WWW.ammso2.com ) and the Export Import Management System Online (EIMSO), Www.eimso.com) - are web-based PBL tools designed to be used for international business projects. The purpose of this paper is to briefly explain PBL, show how the software work, the benefits provided to both students and instructors using the software and discuss both pedagogical issues and student reactions based on a survey questionnaire.
\end{abstract}

Keywords: Globalisation, internationalisation, strategy, marketing, planning.

\section{INTRODUCTION: PROJECT-BASED LEARNING}

Project-Based Learning is a model that organizes learning around projects. Research projects are complex tasks, based on challenging questions or problems that involve students in design, problemsolving, decision making, or investigative activities. They also provide students with the opportunity to work relatively autonomously over extended periods of time, and culminate in realistic products or presentations (Jones, Rasmussen, and Moffitt, 1997). According to Elayne Shields, PBL incorporates methods from problem-based learning, cooperative learning, constructive learning, active learning and project management theory. Developing workplace know-how should be the main objective of any project-based learning. Elayne shields identifies five competency areas that projects should address: 1) the ability to identify, organize, plan and allocate resources, 2) interpersonal skills, 3) the ability to acquire and use information, 4) the ability to understand complex interrelationships, and 5) the ability to work with a variety of technologies.

Interactive learning, made possible with the arrival of the World Wide Web, has a lasting impact on a person's ability to retain and understand information as described by the classic study conducted by 
the National Training Laboratory's "Learning Pyramid" (DeKanter, 2005). As represented by the statistics on retention rates below, students will have a greater opportunity to learn and retain the information presented in the web based tools than by simply learning the material in a traditional way:

- Teach others/use immediately 90\%

- Practice by doing 75\%

- Discussion Group $50 \%$

- See a demonstration 30\%

- Learn from audio/visual 20\%

- Reading $10 \%$

- Lecture 5\%

Using-web based learning tools is a natural progression for education. currently four out of five managers under the age of 34 have significant video game experience. With this new "gamer" group also comes a new belief system, which arguably better equips gamers than non-gamers (Beck and Carstens, 2005). Beck and Carstens have shown that games and simulations help to build user's confidence in their own abilities, develop leadership skills and improve self-dependence.

Despite the lack of a universally accepted model or theory of PBL, five criteria should be considered when determining the effectiveness of a model: centrality, driving question, constructive investigations, autonomy, and realism. First, projects must be central to the curriculum and not peripheral; meaning that projects are the curriculum. Second, projects should be designed to force students to encounter and struggle with the central concepts and principles of the discipline. Third, projects should create constructive investigation that involves inquiry, knowledge building, and resolution. Fourth, projects are student-driven and not instructor-lead or scripted. Fifth, projects should be realistic and relate to the real world (Thomas, 2000). According to Elayne Shields, PBL focuses on both the process and product of an assignment, develops the ability to adapt to change, and develops team dynamic and project management skills.

\section{JAI INTERANTIONAL BUSINESS TEACHING AND LEARNING TOOLS}

The challenge most software designers face, as noted by Kirkley and Kirkley, is to figure out how to bring the real world into the classroom or training environment (making the project realistic). The JAI interactive teaching and learning tools are designed to bring realism into the classroom and beyond. This will enable students to identify global business opportunities, develop international marketing plans and exporting strategies, as well as prepare all the necessary documents online from anywhere in the world. Students, working individually or in groups, have an opportunity to integrate all functional business areas, assess the impact of environmental forces on business decisions and bridge the gap between theory and practice. More specifically, students learn how to:

- Perform a situation analysis of a company in a global context

- Research global markets for a product/service

- Identify high potential country markets for company's produce/service

- Conduct competitive analysis

- Enter foreign markets 
- Develop international marketing/export plans and strategies

- Use internet resources and information effectively.

These web-based tools provide instructors the ability to bring the real world into the classroom, while offering an interesting and stimulating environment.

Some of the instructor benefits include:

- Minimum preparation time

- Instructor's manual and PP presentations

- Ability to monitor student progress and review completed projects online

- Real-time business tools

- User friendly (need basic computer skills only; detailed instructions are provided to guide you in completing the process)

- Interactive and integrative (students can work independently or as a members of a team from anywhere in the world)

- Cognitive and experiential (hands-on)

- Resourceful and innovative (up-to-date web sites and targeted resources are included for each phase)

- Multidimensional (can be used for global, regional and, individual country markets).

\section{THE GLOBAL MARKET POTENTIAL SYSTME ONLINE@ (GMPSO)}

The GMPSO enables students to perform a company situation analysis, determine a company's readiness to internationalize and identify the best country markets for the company's products or services (www.qlobalmarketpotential.com).

PHASE 1 - SITUATION ANALYSIS

\begin{tabular}{|c|c|c|c|c|c|c|c|}
\hline 1.1 & 1.2 & 1.3 & 1.4 & 1.5 & 1.6 & 1.7 & \\
\hline$\frac{\text { Company }}{\text { Analysis }}$ & $\frac{\text { Intl }}{\text { Involvement }}$ & $\begin{array}{l}\text { Industry } \\
\text { Analysis }\end{array}$ & $\frac{\text { Target }}{\text { Market }}$ & $\begin{array}{l}\text { Product } \\
\text { Profile }\end{array}$ & $\frac{\text { Global }}{\text { Readiness }}$ & S.W.O.T. & $\frac{\text { Phase 1 }}{\underline{\text { Report }}}$ \\
\hline
\end{tabular}

Objective: The objective of Phase 1 is to conduct an in-depth situation analysis of a company by following the procedure below.

- Choose an industry and a company within the industry

- Select:

- A specific product line / service of the chosen company (If more than one product lines / services are available)

- If you choose a retail establishment as your company, you need to decide on the merchandise mix to be included in your overseas operation (e.g. Target, McDonald's, Starbucks, Best Buy etc).

- Conduct an internal analysis of the company

- Determine the international involvement, if any, of the company

- Conduct a product / market analysis for the company's chosen product (s) or service(s) 
- Evaluate the performance of the chosen industry and identify the trends in the industry

- Determine the company's readiness to do business in the international arena

- Conduct a S.W.O.T (Strengths, Weaknesses, Opportunities and Threats) analysis of the company

- Briefly state your conclusions and recommendations for Phase 1

- Generate your Phase 1 Report.

PHASE 2 - COUNTRY SELECTION

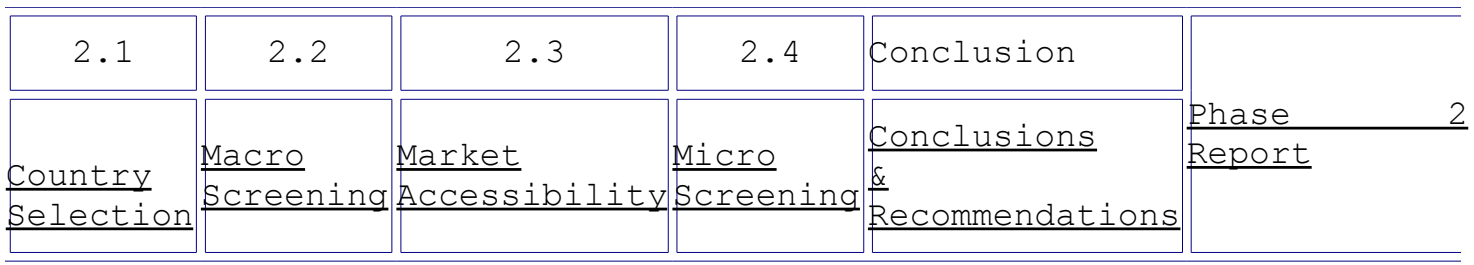

Objective: The objective of Phase 2 is to identify high potential country markets for your company's product(s) or service(s) for the purpose of either exporting or manufacturing products in the selected markets by following the procedure below.

- Research and select a minimum of five (5) and a maximum of ten (10) countries. These are the country markets which you will analyze, score, and rank throughout phase 2

- Select criteria (macro level / market accessibility / micro-level) that are essential in determining high potential country markets for your company's product(s) / service(s)

- Determine the relative importance (weight) of each criterion on a scale of 1-100. Enter the values and rank on a scale of 1-5 relative to the other countries values

- State your conclusions and recommendations for Phase 2

- Generate the Phase 2 Report.

\section{THE GLOBAL MARKETING MANAGEMENT SYSTEM ONLINE@ (GMMSO)}

The GMMSO enables students to do the GMPSO (phase 1 and 2) plus an indepth market and competitive analysis of best markets and develop the marketing plan (wWw.gmmso2.com).

PHASE 3 - IN-DEPTH MARKET ANALYSIS

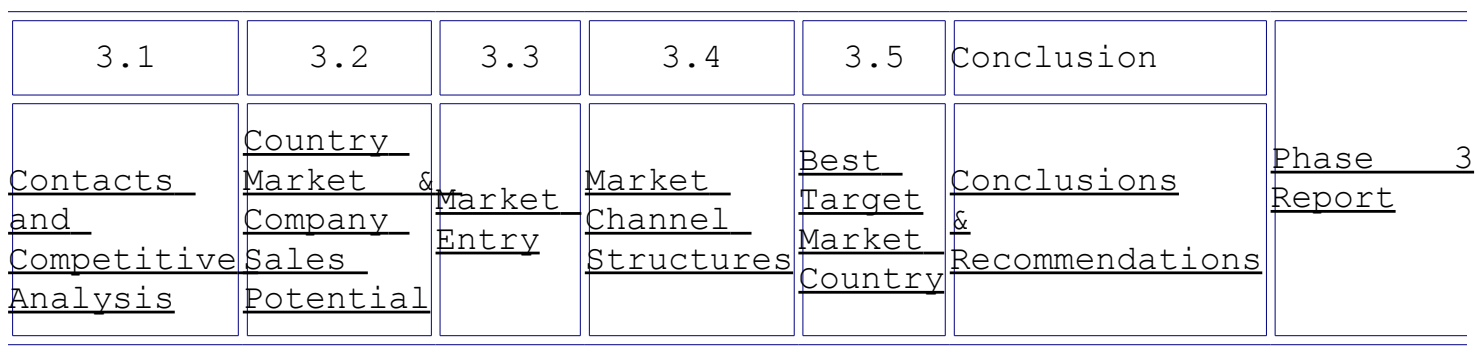


Objective: The objective of Phase 3 is to identify the best target market country for the company and its products/services by using the following procedure:

- Select the top two countries based on the country scores in Phase 2.

- Develop business contacts who are more familiar with each of the identified target market countries:

- Agents/Distributors

- Government agencies

- Associations and organizations

- Letters of inquiry

- Develop a profile for the top two (2) competitors in the target market in each country. Include for each an assessment of product attributes and benefits, market share, sales, market positioning, and competitor strengths and weaknesses

- Determine the company's market sales potential and market share

- Analyze in detail the current market-entry conditions for each target market country. Include for each an analysis of payment and financing methods, import and export regulations, licensing, registrations, transportation, and documentation

- Analyze the existing distribution channels in each country to determine whether they are appropriate for your particular product/service

- Select the market with the highest potential by ranking each country using the following five categories:

1 Quality and strength of your contact in each country

2 Degree and level of market competition in each country

3 Highest market sales potential in each country

4 Most favorable market entry conditions in each country

5 Most suitable market channel structure in each country

- State your conclusions and recommendations for Phase 3

- Generate Phase 3 Report

PHASE 4 - ENTRY STRATEGY \& MARKETING PLAN

\begin{tabular}{|c|c|c|c|c|c|c|c|}
\hline 4.1 & 4.2 & 4.3 & 4.4 & 4.5 & 4.6 & 4.7 & \multirow[b]{2}{*}{ Phase } \\
\hline & \multirow{4}{*}{$\begin{array}{l}\text { Market } \\
\text { Segmentati } \\
\underline{\text { on }}\end{array}$} & $\frac{\text { Sales, }}{\text { Profit }}$ & Pricing & Promotio & Distributi & \multirow{4}{*}{ Budgetin } & \\
\hline Entr & & MroldLs & Strated & & on & & Report \\
\hline$y$ & & Donstrat & y & strategy & Strategy & & \\
\hline Mode & & & Plan & \& Plan & Plan & & \\
\hline
\end{tabular}

Objective: The objective of Phase 4 is to develop entry strategies and marketing plans that are based on company strengths relative to the competition (some of the information collected in Phases 1 and 3 can be useful in completing Phase 4.)

- Determine the best mode of entry for the company's product by evaluating alternative entry strategies

- Develop marketing strategies and action plans that will most successfully penetrate the target market country 
- Segment the target market country using demographic, geographic, socio-cultural and/or psychographic variables.

- Based on in-depth analysis and estimates of sales potential for the target market country (Phase 3), develop sales and profit objectives for the targeted market segments over the duration of the plan

- Develop market penetration and coverage objectives that fully exploit market opportunity

- Determine whether the company should create, extend, and/or adapt its current product/service

- Determine the best pricing strategy and method for the company's product after investigating terms of sale and value added costs in the target market

- Develop an effective promotional strategy by carefully matching company resources with perceived product/service benefits and buyer behavior in the target market

- Determine the best distribution strategy and channels for the company's product/service in the target market.

- Based on entry strategy and the developed marketing mix, create an international marketing budget and profit plan that includes a cost of entry strategy, forecast of future sales, projected income statement, and breakeven analysis for the target market

- Consider the company's existing organizational structure and whether or not it serves the objectives of the company as best it could

- Make conclusions and recommendations

- Generate Phase 4 Report

- Prepare a written report

\section{THE EXPORT IMPORT MANAGEMENT SYSTEM ONLINE@ (EIMSO)}

The EIMSO enables students to do the GMPSO (phase 1 and 2) plus develop the export marketing plan and prepare the necessary documents online (www.eimso.com).

PHASE 3 - EXPORT MARKETING PLAN

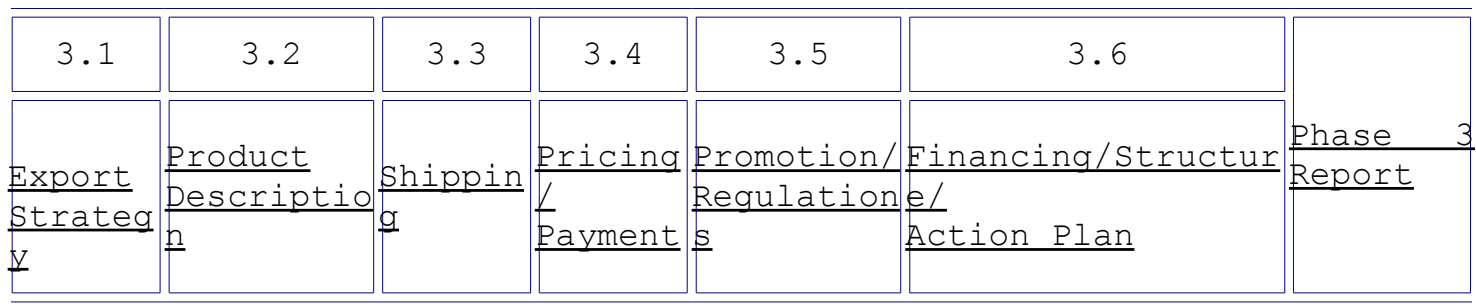

Objective: The objective of Phase 3 is the development of the Export Marketing Plan. It consists of six sections, conclusions and recommendations, and the phase 3 report.

Phase 3 provides a section with export documents. These documents are in either Word or PDF format. The documents in Word can be filled out 
and saved if need be, but the PDF files must be printed and filled out. The format of each document is stated next to its respective link.

\section{SURVEY RESULTS}

An anonymous survey questionnaire was administered to 71 students. Of the 71 students, 55 were undergraduate students enrolled in two sections of international marketing and 16 were MBA students in the Global Strategy Course. Both taught by the author, who used the GMMSO for their project during the fall semester of 2005. It should be noted that the majority of the undergraduate students and a few MBA students, had used the GMPSO software in the past. The survey was a Likert Scale, 1 (Strongly Disagree) to 5 (Strongly Agree). The purpose of the survey was to determine: 1 . the usability, 2. usefulness, and 3. level of engagement of the JAI software. Since there were no significant differences between the responses of undergraduate and graduate students, the results were combined. Overall, the students' responses indicate that the JAI software:

- Enhanced their understanding of international business concepts and practices

- Enabled them to integrate and evaluate environmental factors (such cultural, economic, political and regulatory) affecting the decisions of firms pursuing global business opportunities

- Allowed the integration and application of various business disciplines, in addition to international business, such as management, marketing and finance

- Created an engaging environment that requires them to use critical thinking skills and enhance their decision making and team working skills

- Improved their international business research skills and increase their awareness of useful online resources.

In addition, students overwhelmingly preferred (55 out of 71 surveyed) to complete the project on a group rather than on an individual basis and 65 out of 71 preferred a mixture of class-time and personal-time to complete the project as opposed to using strictly class-time or personal-time. Table 1 shows the frequency of each response while Table 2 shows a statistical analysis of the answers.

Table 1: Survey Results: Frequency Distribution

\begin{tabular}{|c|c|c|c|c|c|}
\hline & $\mathrm{SD}$ & $\mathrm{D}$ & $\mathrm{N}$ & A & SA \\
\hline \multicolumn{6}{|l|}{ Usability } \\
\hline $\begin{array}{l}\text { A. The instructions provided were clear and helpful } \\
\text { in completing the project. }\end{array}$ & 1 & 5 & 5 & 44 & 16 \\
\hline $\begin{array}{l}\text { B. The web sites featured in the GMMSO were helpful } \\
\text { in conducting research and completing the project }\end{array}$ & 2 & 6 & 13 & 37 & 13 \\
\hline $\begin{array}{l}\text { C. The case samples were helpful in completing the } \\
\text { project. }\end{array}$ & & 1 & 3 & 32 & 35 \\
\hline $\begin{array}{l}\text { D. The format of each phase was useful in completing } \\
\text { the project. }\end{array}$ & & 4 & 13 & 38 & 16 \\
\hline E. The GMMSO seemed to be laid out logically. & & 3 & 5 & 42 & 21 \\
\hline $\begin{array}{l}\text { G. The instructor's level of involvement was } \\
\text { adequate. }\end{array}$ & 2 & 3 & 9 & 38 & 19 \\
\hline
\end{tabular}


F. The GMMSO should be completed individually (vs. groups).

Usefulness

A. The GMMSO enabled me to evaluate a company and the company's level of international involvement. B. The GMMSO provided me with the opportunity to use business concepts and practices I acquired in other business courses.

C. The GMMSO enabled me to become familiar with a good number of useful web-based information sources. D. The GMMSO increased my understanding of international business.

E. The GMMSO allowed me to determine a company's readiness to internationalize.

F. The GMMSO increased my understanding of different countries around the world.

G. The GMMSO enhanced my knowledge of cultural forces and its impact on business.

H. The GMMSO increased my understanding and appreciation of the impact of a country's economic and political system on business.

I. The GMMSO helped me identify high potential country markets for selected products or services. J. The system allowed for an in-depth analysis of high market potential countries.

K. The system enabled me to determine market potential for my product/service.

L. The system enabled me to perform a complete competitive analysis.

M. GMMSO simplified selecting the best entry strategy.

N. GMMSO was valuable in developing an effective marketing plan.

O. GMMSO was useful in developing projected Profit \& Loss statements

P. The GMMSO increased my understanding of the importance certain environmental factors have in selecting best markets for a given product/service. Q. I feel more businesses classes should try to incorporate projects like the GMMSO.

Level of Engagement

A. The GMMSO provided me with the opportunity to make use of my critical thinking skills.

B. The GMMSO improved my web-based research skills.

C. The GMMSO improved my team working skills.

D. The GMMSO improved my decision-making skills.

E. The GMMSO was more challenging and beneficial than other non-web based business projects I have done.

\begin{tabular}{|c|c|c|c|c|}
\hline 43 & 12 & 5 & 8 & 3 \\
\hline & 3 & 3 & 46 & 19 \\
\hline & 6 & 10 & 42 & 13 \\
\hline & 3 & 8 & 40 & 20 \\
\hline & 12 & 4 & 38 & 17 \\
\hline & 6 & 11 & 43 & 11 \\
\hline 1 & 4 & 16 & 33 & 17 \\
\hline 1 & 7 & 13 & 40 & 10 \\
\hline 2 & 3 & 11 & 41 & 14 \\
\hline & 4 & 8 & 41 & 18 \\
\hline 1 & 3 & 7 & 45 & 15 \\
\hline & 4 & 12 & 41 & 14 \\
\hline 1 & 6 & 11 & 41 & 12 \\
\hline 2 & 3 & 16 & 34 & 16 \\
\hline 1 & 6 & 18 & 36 & 10 \\
\hline 4 & 12 & 19 & 24 & 12 \\
\hline & 5 & 9 & 42 & 15 \\
\hline 5 & 7 & 17 & 32 & 10 \\
\hline 1 & 2 & 5 & 46 & 17 \\
\hline 2 & 4 & 13 & 32 & 20 \\
\hline 1 & 6 & 12 & 34 & 18 \\
\hline 1 & 6 & 13 & 38 & 13 \\
\hline 2 & 3 & 15 & 31 & 20 \\
\hline
\end{tabular}

SD: Strongly Disagree, D: Disagree, N: Neutral, A: Agree, SA: Strongly Agree 
Table 2: Survey Results: Mean and Standard Deviation

\begin{tabular}{|c|c|c|}
\hline Usability & Mean & $\begin{array}{c}\text { St. } \\
\text { Dev. }\end{array}$ \\
\hline $\begin{array}{l}\text { Instructions provided were clear } \\
\text { Website resources provided were helpful } \\
\text { Case samples provided were helpful } \\
\text { Format of each phase was useful } \\
\text { Software is laid out logically }\end{array}$ & $\begin{array}{l}3.97 \\
3.74 \\
4.42 \\
3.93 \\
4.14\end{array}$ & $\begin{array}{l}.713 \\
.958 \\
.625 \\
.639 \\
.552\end{array}$ \\
\hline Usefulness & Mean & $\begin{array}{l}\text { St. } \\
\text { Dev. }\end{array}$ \\
\hline $\begin{array}{l}\text { For analyzing a company's international involvement } \\
\text { Providing an opportunity to use business concepts } \\
\text { Gain familiarity with useful internet research } \\
\text { sources } \\
\text { Increased understanding of international business } \\
\text { Determine company's readiness to internationalize } \\
\text { Increased understanding of different countries } \\
\text { Enhance knowledge of cultural forces on business } \\
\text { Increased understanding of economic and political } \\
\text { factors on business } \\
\text { Helped identify high potential country markets } \\
\text { Allowed an in-depth analysis of potential market } \\
\text { countries } \\
\text { Helped determined market potential for } \\
\text { product/service } \\
\text { Enabled a complete competitive analysis } \\
\text { Simplified selecting best entry strategy } \\
\text { Valuable in developing a marketing plan } \\
\text { Useful in creating projected Profit \& Loss Statements } \\
\text { Better understanding of environmental factors on } \\
\text { market selection }\end{array}$ & $\begin{array}{l}4.14 \\
3.87 \\
4.08 \\
3.84 \\
3.83 \\
3.85 \\
3.71 \\
3.87 \\
4.02 \\
3.08 \\
3.91 \\
3.82 \\
3.83 \\
3.67 \\
3.39 \\
3.94\end{array}$ & $\begin{array}{l}.495 \\
.665 \\
.578 \\
.978 \\
.648 \\
.821 \\
.842 \\
.779 \\
.602 \\
.614 \\
.595 \\
.789 \\
.876 \\
.854 \\
1.60 \\
.626\end{array}$ \\
\hline Level of Engagement & Mean & $\begin{array}{c}\text { St. } \\
\text { Dev. }\end{array}$ \\
\hline $\begin{array}{l}\text { Required critical thinking skills } \\
\text { Improved web-based research skills } \\
\text { Improved my team working skills } \\
\text { Improved my decision-making skills } \\
\text { More challenging/beneficial than non web-based } \\
\text { projects }\end{array}$ & $\begin{array}{l}4.07 \\
3.90 \\
3.87 \\
3.78 \\
3.90\end{array}$ & $\begin{array}{l}.561 \\
.952 \\
.893 \\
.831 \\
.923\end{array}$ \\
\hline
\end{tabular}

In conclusion, the JAI software not only supports but also reinforces the theories and benefits of project-based and interactive learning. The survey results showed that international business projects using JAI software are an excellent way for students to enhance their understanding of international business and bridge the gap between theory and practice. Consequently, business instructors should consider integrating these tools into their curriculum and use them for their international business projects. 
Further research is needed in the area of PBL and JAI software. It is recommended that instructors using the JAI software are also surveyed in order to determine their opinions and experiences with the software.

\section{REFERENCES}

Beck, John and Carstens, Adam (2005). "Get Ready for the Gamer Generation." TechTrends: Linking Research and Practice to Improve Learning, Volume 49, Issue 3 (May/June), 22- 25.

DeKanter, Nick (2005). "Gaming Redefines Interactivity for Learning." TechTrends: Linking Research and Practice to Improve Learning, Volume 49, Issue 3 (May/June), 26-31.

Janavaras \& Associates International, Inc. (2005). http://www.janavaras.com

Jones, B. F., Rasmussen, C., and Moffitt, M. C. (1997). "Real-Life Problem Solving: A Collaborative Approach to Interdisciplinary Learning. Washington, DC: American Psychological Association.

Kirkley, Jamie and Kirkley, Sonny (2005). "Creating Next Generation Blended Learning Environments Using Mixed Reality, Video Games and Simulations." TechTrends: Linking Research and Practice to Improve Learning, Volume 49, Issue 3 (May/June), 42- 53.

Shields, Elayne A (2005). "A Guide to Project-Based Learning." McGraw-Hill On-Line Learning Center, http: //www.mhhe.com/business/management/PBL/

Thomas, John W. (2000). "A Review of Research on Project-Based Learning." The Autodesk Foundation,

http:wWw. autodesk.com/foundation 


\section{Basil J. Janavaras}

Dr. Basil J. Janavaras is Professor of International Business, Department of Marketing and International Business at Minnesota State University, Mankato, MN and an adjunct faculty at Saint Mary's University of Minnesota, Executive MBA Program, Rochester, MN. In addition, he served as Chairperson and Director of the International Business Institute at Minnesota State. He has also served as Director of International Business Studies, Master of International Management (MIM) Program, Graduate School of Business, University of St. Thomas (UST), St. Paul, MN, USA..

Dr. Janavaras (http://www.business.mnsu.edu/basilj) has taught and lectured abroad including the former Soviet Union, Austria, Canada, Greece, Hungary, Poland, Taiwan, and other Asian countries. He has assisted several public institutions and small and mid-sized companies with their efforts to internationalize.

$\mathrm{He}$ is the author of Global Marketing Management System book previously published by Pearson Education, Inc. He has also developed two other online software systems:

- Global Market Potential is a management tool designed to conduct a company situation analysis and identify high potential country markets.

- Export-Import Management System Online (www.eimso.com) is a management planning tool designed to assist companies with their export marketing strategies and operations.

$\mathrm{He}$ is the founder, president and CEO of Janavaras \& Associates International, Inc. (JAI), a global management training and consulting firm (www.janavaras.com), and co-owner of Odyssey Gifts (www.odysseygifts.com), a family owned retail business of better quality gifts and collectibles.

He serves on the board of directors and is a member of several academic and professional business organizations, including the Marketing Management Association, Greek Marketing Academy, The Academy of International Business, the U.S. Dept. of Commerce Minnesota District Export Council, the Minnesota World Trade Association, the Minnesota International Center, St. Paul/Minneapolis Committee on Foreign Relations. He is listed in several editions of "Who's Who".

\section{Emanuel Gomes}

Dr. Emanuel Gomes is a Senior Lecturer in Corporate Strategy, Faculty of Business, Environment and Society at Coventry University, UK. He is the Programme Manager for the MBA International Business and the MSC International Business. He teaches various modules such as 'Strategic Management,' 'International Strategic Management,' 'Managing Partnerships' and 'Managing Partnerships, Strategic Alliances and Mergers and Acquisitions.'

Dr. Gomes has participated in international conferences in various countries such as, the UK, Russia, Ireland, Northern Ireland, Portugal, Angola. He has also worked or participated in international projects in countries including, England, Scotland, Spain, Portugal, Cape-Verde and the USA. He also serves on the Scientific Committee act as Program Co-Chair in some international conferences, including the Global Business \& Technology Association, the Management of International Business and Economics Systems Conference, the International Conference on Strategic Developments in Services Marketing.

His research interest is in the areas of mergers, acquisitions and strategic alliances. 